КРИМІНАЛЬНИЙ ПРОЦЕС ТА КРИМІНАЛІСТИКА;

СУДОВА ЕКСПЕРТИЗА; ОПЕРАТИВНО-РОЗШУКОВА ДІЯЛЬНІСТЬ

УДК 343.98

DOI https://doi.org/10.32844/2618-1258.2019.5-1.39

АРЕШОНКОВ В.В.

\title{
ЩОДО МЕТИ ПОПЕРЕДНІХ КРИМІНАЛІСТИЧНИХ ДОСЛІДЖЕНЬ У РОЗСЛІДУВАННІ КРИМІНАЛЬНИХ ПРАВОПОРУШЕНЬ
}

Різноманітні аспекти проведення попередніх криміналістичних досліджень досліджувались науковцями починаючи ще 3 50-х років минулого століття. Проте донині залишається низка дискусійних питань як теоретичного, так і теоретико-прикладного характеру. Одним із проблемних питань, яке потребує додаткової деталізації, $є$ мета попередніх досліджень, оскільки визначення попередніх криміналістичних досліджень не розкривають її повною мірою. На основі аналізу наукових джерел, як окремих напрямів криміналістичної техніки, так і загальних робіт цієї проблематики, було визначено загальну мету попередніх криміналістичних досліджень - інформація про кримінальне правопорушення, а також окреслено напрями подальшого використання такої інформації. Проведене дослідження дало змогу дійти висновків, що з огляду на двоїсте розуміння мети попередніх криміналістичних досліджень варто розділяти мету як кінцевий результат власне самих досліджень, що добре простежується через конкретні завдання, які ними можуть бути вирішені, та мету як напрям подальшого використання отриманої інформації, хоча інколи автори змішують ці цілі. Метою попередніх криміналістичних досліджень як різновиду техніко-криміналістичних досліджень є встановлення орієнтуючої інформації щодо окремих осіб, матеріальних об'єктів, а також фактів і обставин вчиненого злочину (наприклад, природи та сутності об'єктів, які виявлені в процесі слідчої (розшукової) дії, об'єктів, сліди яких виявлені на місці проведення слідчої (розшукової) дії, обставин вчинення злочину, особи (осіб), яка вчинила злочин або була присутня під час його вчинення чи в інший час на місці проведення слідчої (розшукової) дії тощо). Відповідно, напрями використання такої інформації досить різноманітні: від висунення і перевірки окремих та загальних версій щодо події злочину, розшуку злочинця й засобів та знарядь злочину до підготовки, призначення та оцінки криміналістичних експертиз. Деталізація мети попередніх криміналістичних досліджень, на нашу думку, підкреслює важливість проведення досліджень цієї категорії під час слідчих (розшукових) дій, особливо невідкладних, а також виняткове значення інформації, отриманої в результаті таких досліджень, у розкритті та розслідуванні кримінальних правопорушень.

Ключові слова: криміналістична техніка, техніко-криміналістичні дослідження, попередні криміналістичні дослідження, мета попереднього дослідження, розслідування кримінального правопорушення.

Various aspects of previous criminalistic research have been studied by scientists since the 1950s. However, a number of debates remain to this day, both theoretical and theoretical. One of the problematic issues that needs further detail is the purpose

(C) АРЕШОНКОВ В.В. - кандидат юридичних наук, старший науковий співробітник, провідний науковий співробітник наукової лабораторії з проблем протидії злочинності (Навчально-науковий інститут № 1 Національної академії внутрішніх справ) 
of prior research, as existing definitions of previous criminalistic research do not fully expose it. On the basis of the analysis of scientific sources, both from particular areas of forensic technology and the general works of this issue, the general purpose of previous criminalistic research was determined - information about criminal offense, and also directions of further use of such information. The research made it possible to conclude that based on a dual understanding of the purpose of previous forensic research, it is necessary to divide the goal as the end result of the research itself, which is well traced through the specific tasks that can be solved and the goal as directions for further use of the obtained information, although sometimes the authors mix goal (goal) data with one another. The purpose of previous criminalistic research, as one of the varieties of forensic investigations, is to establish indicative information about individuals, material objects, and the facts and circumstances of the crime (such as the nature and nature of the objects identified in the course of the investigation (investigative actions; objects whose traces were found at the place of the investigative (investigative) action; the circumstances of the crime; the person (persons) who committed the crime or were present at the time of its commission or at other times at the place of the investigator (search these) actions, etc.). Accordingly, the lines of use of such information are quite diverse, ranging from the nomination and verification of individual and general versions of the event of the crime, the search for the offender and the means and tools of the crime, and ending with the preparation, assignment and evaluation of criminalistic expertise. The detailing of the purpose of previous forensic investigations, in our opinion, underscores the importance of conducting investigations of this category in the course of investigative (investigative) actions, especially urgent ones, as well as the exceptional importance of the information obtained from such investigations in the detection and investigation of criminal offenses.

Key words: forensic technology, forensic research, technical-criminalistic research, purpose of preliminary criminalistic research, investigation of a criminal offense.

Вступ. Різноманітні аспекти проведення попередніх криміналістичних досліджень висвітлювались 3 50-х років минулого століття у наукових роботах О.І. Дворкіна, О.М. Зініна, В.О. Комахи, М.О. Корнієнка, А.В. Кофанова, В.С. Мітрічева, І.В. Пирога, Ю.Г. Плесовських, М.О. Селіванова, В.О. Снєткова, С.О. Торопова, М.Г. Щербаковського, В.М. Хрустальова та багатьох інших.

Зазначені науковці зробили суттєвий внесок у розвиток такого різновиду техніко-криміналістичних досліджень, як попередні дослідження, проте донині залишається низка дискусійних питань, як теоретичного, так і теоретико-прикладного характеру, що не знайшли свого однозначного трактування в наукових джерелах та, відповідно, достатнього розуміння тими особами, які можуть проводити такі дослідження та використовувати їх результати для розслідування кримінальних правопорушень. Одним із проблемних питань, яке потребує певної деталізації, $\epsilon$ мета попередніх досліджень, оскільки визначення попередніх криміналістичних досліджень не розкривають ії повною мірою.

Окрім цього, нині можливість проведення попередніх криміналістичних досліджень не передбачена в жодному нормативно-правовому акті, а тому слідчі та інші особи, які володіють спеціальними криміналістичними знаннями, досить часто нехтують цим різновидом техніко-криміналістичних досліджень. Саме тому деталізація мети попередніх криміналістичних досліджень, на нашу думку, потрібна для акцентування на важливості результатів цього різновиду техніко-криміналістичних досліджень у розкритті та розслідуванні кримінальних правопорушень.

Постановка завдання. Метою статті $є$ деталізація мети попередніх криміналістичних досліджень, а також окреслення основних напрямів використання інформації, отриманої в результаті таких досліджень, у розкритті та розслідуванні кримінальних правопорушень.

Результати дослідження. Загалом мета, згідно з Великим тлумачним словником сучасної української мови, - це те, до чого хтось прагне, чого хоче досягти; ціль [1, с. 661]. У нашому випадку щодо попередніх криміналістичних досліджень це кінцевий результат вивчення певного об'єкта.

У криміналістиці такий кінцевий результат попередніх досліджень (їхню мету) автори визначають по-різному, інколи значно звужуючи їі, зазначаючи тільки основну мету або взагалі до кінця не розкриваючи ii. Так, С.О. Торопов твердить, що основна мета попередніх досліджень на місці події - невідкладне отримання за обмежений проміжок часу інформації про обставини скоєного за допомогою вогнепальної зброї злочину, яка необхідна для розкриття злочину по гаря- 
чих слідах [2, с. 486]. Із наведеного автором твердження, яке, до речі, є занадто вузьким, оскільки, наприклад, визначаючи різновид зброї за стріляною з нею гільзою, вирішується ще одне завдання (класифікаційне), не пов'язане з обставинами вчинення злочину, тобто ситуаційними завданнями, добре простежується двоїсте розуміння мети попередніх досліджень. Тобто варто розділяти мету як кінцевий результат власне самих досліджень, що добре простежується через конкретні завдання, які ними можуть бути вирішені, та мету як напрям подальшого використання отриманої інформації, хоча інколи автори змішують ці цілі. У цьому разі кінцевий результат дослідження - встановлення обставин злочину, а напрямами використання такої інформації можуть бути як розшук злочинця за гарячими слідами, так і побудова версій й інші.

В.Д. Корма зазначає, що основна мета попередніх досліджень, окрім виявлення ознак, які $є$ підставами для порушення кримінальної справи, також отримання розшукової інформації, під якою він розуміє сукупність даних, які інтерпретовані, оброблені та проаналізовані з метою розслідування злочину, розшуку злочинців та представлення доказів у кримінальному процесі [3, c. 28].

Ми вважаємо, що оскільки, окрім інформації про осіб, які вчинили злочин, попередніми дослідженнями можуть бути встановлені й інші дані, наприклад, щодо придатності виявлених слідів для ідентифікації, встановлення необхідності вживання спеціальних заходів, спрямованих на збереження доказових властивостей об'єктів, встановлення їх відношення до події, яка розслідується тощо [4, с. 5], більш доречно говорити про отримання орієнтуючої інформації або інформації орієнтуючого характеру, яка, в тому числі, може орієнтувати на розшук злочинців за гарячими слідами.

B.M. Хрустальов зазначає, що власне орієнтуюча інформація - це дані про факти, наявність яких передбачається чи встановлюється ймовірно [5, с. 38]. 3 цього приводу ми вважаємо, що виділення інформації в цю групу відбувається не за критерієм достовірності інформації (категорична або ймовірна), оскільки висновки дослідження можуть бути і категоричними (наприклад, відбиток пальця руки, залишений потерпілим), а за характером такої інформації у кримінальному провадженні - вона має не доказове, а орієнтуюче значення.

Таким чином, метою попередніх криміналістичних досліджень $є$ встановлення орієнтуючої інформації щодо окремих осіб, матеріальних об'єктів, а також фактів і обставин вчиненого злочину, а саме:

- природи та сутності об'єктів, які виявлені в процесі слідчої (розшукової) дії (наприклад, наркотичні засоби, мікрооб'єкти тощо), придатності об'єктів до подальшого експертного дослідження, їх правильного вилучення і збереження, відношення до події, що розслідується;

- об'єктів, сліди яких виявлені на місці проведення слідчої (розшукової) дії (наприклад, транспортні засоби, знаряддя зламу, вогнепальна зброя, взуття тощо);

- обставин вчинення злочину (у тому числі його механізму, наприклад, визначення напряму, відстані та місця проведення пострілу тощо) або здійснення інших дій, які стосуються кримінального провадження;

- особи (осіб), яка вчинила злочин або була присутня під час його вчинення чи в інший час на місці проведення слідчої (розшукової) дії;

- потерпілої особи (осіб) у разі виявлення невпізнаного трупа.

Щодо напрямів подальшого використання отриманої в результаті попередніх досліджень інформації необхідно зауважити, що вона є корисною не тільки для розшуку злочинців за гарячими слідами та, відповідно, швидкого розкриття злочину, а й з інших причин.

Наприклад, М.Г. Щербаковський доречно зауважує, що за результатами попередніх досліджень висуваються окремі версії щодо елементів злочинного діяння (кількості злочинців, часу вчинення злочину, знарядь злочину, предмета посягання, дій злочинців тощо), а системний аналіз усього комплексу слідів за результатами попереднього дослідження кожного допомагає висунути загальні версії вчиненого злочину [6, с. 61].

У західних країнах, у поширеній теорії реконструкції або моделювання злочину, в межах якої розглядається також реконструкція місця злочину («crime scene reconstruction»), що являє собою діяльність, результатом якої, по суті, є науково обгрунтована версія щодо механізму події на місці скоєння злочину, чільне місце відводиться криміналістичним дослідженням, які, в тому числі, проводяться в «польових» умовах, тобто на місці події. У наукових джерелах, присвячених реконструкції місця злочину, детально викладені, наприклад, особливості використання експрес тестів на наявність наркотичних засобів, продуктів пострілу, продуктів вибуху, крові, інших продуктів життєдіяльності людини, визначення траєкторії польоту кулі тощо [7, с. 201-205]. 3 цього 
приводу Р. Гарнер та Т. Бевел слушно зауважують, що з точки зору реконструкції місця злочину, непроведення дослідження (аналізу) об'єктів на місці події може суттєво обмежити контекст інформації, яка потрібна особі (аналітику), яка здійснює розслідування [8, с. 105].

Важливу роль результати попередніх криміналістичних досліджень відіграють також у процесі моделювання особи невідомого злочинця або ж створення його криміналістичного портрету. Для створення такого «портрету», який є системою відомостей, що відбились у матеріальних та ідеальних слідах злочину, про соціальні, біологічні та психологічні властивості особи, яка вчинила злочин, здійснюється комплексний міждисциплінарний аналіз масиву всієї наявної інформації, частина якої отримана якраз шляхом проведення попередніх криміналістичних досліджень. Отримана таким чином інформація використовується для визначення напрямів розшуку злочинця, висунення та розробки криміналістичних версій, а також здійснення прогнозування його подальшої поведінки [9, с. 110].

Окрім побудови версій, М.О. Корнієнко говорить про використання результатів попередніх досліджень у тактичному плані для планування, підготовки та проведення допиту, оскільки ними можуть обгрунтовуватись зміст і спосіб того чи іншого тактичного прийому допиту, а також у процесі підготовки та призначення експертиз, оскільки отримані результати сприяють прийняттю рішення про призначення експертизи, визначення часу їх призначення, відбору необхідних порівняльних зразків, визначення переліку питань на експертизу, а також у подальшій оцінці висновку експерта [10, с. 18-23].

Щодо власне оцінки висновку експерта, то це твердження потребує деякого уточнення, оскільки його неправильне розуміння особами, які здійснюють кримінальне провадження, може призвести до виникнення проблем у процесі розслідування та, відповідно, призначення необгрунтованих повторних експертиз. Так, ми категорично не погоджуємось із думкою, що попереднє дослідження може бути здійснено після судово-експертного дослідження 3 метою його перевірки і оцінки [3, с. 8]. Це суперечить самій сутності таких досліджень, оскільки, як зазначалось вище, попередніми вони є тому, що проводяться до експертних досліджень і саме тому їх висновки мають попередній характер. Окрім цього, для оцінки судово-експертного дослідження сторони кримінального провадження вивчають висновок експерта, а не сам об'єкт, як у попередньому дослідженні.

Також не можна погодитись із думкою, що теоретичне та практичне знайомство з основами та методами попередніх досліджень дає змогу більш точно оцінювати наукову обгрунтованість методів, використаних експертом, а також перевірити, чи всі сучасні методи аналізу застосовані у процесі проведення експертизи [10, с. 20]. Хоча дійсно оволодіння зазначеною інформацією і підвищує рівень спеціальних знань слідчого, разом із тим, по-перше, все ж таки малоймовірним $\epsilon$ те, що знання слідчого будуть достатніми для того, щоб визначитись із доречністю і повнотою використаних у конкретній ситуації методів експертом - особою, процесуальний статус якої, згідно з Кримінальним процесуальним кодексом України (далі - КПК України), зобов'язує її володіти повною мірою спеціальними знаннями в певній галузі науки і техніки, по-друге, згідно 3 п. 1.4. інструкції про призначення та проведення судових експертиз та експертних досліджень, затвердженої Наказом Міністерства юстиції України № 53/5 від 08.10.1998 р. визначення способу проведення експертизи (вибір певних методик та методів дослідження) належить саме до компетенції експерта, а не когось іншого, по-трете, методи, які застосовуються до одного і того самого об'єкта в «польових» та «лабораторних» умовах, можуть суттєво відрізнятись (наприклад, у процесі вивчення речовини, схожої на наркотичну, на місці події застосовуються хімічні проби у вигляді експрес-тестів, а в процесі експертизи матеріалів, речовин та виробів як більш складні хімічні методи, так і інші - оптичні, хроматографічні, мас-спектрометричні тощо), таким чином знання методів попередніх досліджень не завжди дає змогу досконало розбиратись в інструментальних методах експертних досліджень.

На нашу думку, результати попередніх досліджень дійсно можуть вплинути на оцінку експертного дослідження, а точніше, можуть стати підставою більш ретельного вивчення та оцінки висновку експерта у випадку суттєвої різниці із результатами експертизи з одного і того самого питання. Проте все ж таки викликати обгрунтовані сумніви в достовірності результатів експертизи вони можуть тільки за наявності й інших суттєвих невідповідностей із матеріалами провадження, оскільки навіть у разі письмового оформлення результатів попередніх досліджень у них не буде описової частини, яку можна було б порівняти з висновком експерта, а самі по собі протилежні за змістом висновки можуть пояснюватись більшою глибиною та складністю експертних досліджень порівняно з попередніми дослідженнями. 
3 приводу саме оцінки висновків експертиз значення мають не стільки результати попередніх досліджень конкретних об'єктів, скільки, як зазначалось вище, володіння особами, які здійснюють розслідування та й іншими учасниками кримінального провадження, методологією попередніх досліджень. Проте такі знання та навички дають змогу, на наш погляд, не стільки оцінювати наукову обгрунтованість та повноту методів (хоча у виключних випадках таке також може мати місце), а більше зрозуміти надані відповіді на поставлені питання, які в резолютивній частині висновку експерта подані в чіткій та лаконічній формі, що не дає змоги відтворити причини їх надання та технологію конкретного експертного дослідження.

Щодо використання результатів попередніх досліджень потрібно зауважити, що вони можуть бути використані для підбору тактичних прийомів та визначення особливостей не тільки допиту, а й інших слідчих (розшукових) дій, наприклад, того ж слідчого огляду, обшуку, освідування тощо. Тим самим може бути суттєво підвищена ефективність їх проведення. Наприклад, О.А. Бєлов зазначає, що виявлені на місці події сліди та їх попереднє дослідження можуть стати початком цілеспрямованого пошуку інших слідів злочину, що, зрештою, підвищує ефективність огляду загалом [11]. I дійсно, якщо, наприклад, на місці вибуху, де за попередньою інформацією його причиною могло стати порушення правил безпеки із газовим обладнанням, виявлені фрагменти закопчених об'єктів та попереднім дослідженням встановлено, що це частини детонатору або годинникового механізму, то це буде свідчити про кримінальну природу вибуху та, відповідно, призведе до більш цілеспрямованого пошуку інших слідів злочину.

Ще одним важливим напрямом використання результатів попередніх криміналістичних досліджень є вирішення питання про визнання об'єкта речовим доказом. Оскільки згідно зі ст. 98 КПК України речовими доказами є матеріальні об'єкти, які були знаряддям вчинення кримінального правопорушення, зберегли на собі його сліди або містять інші відомості, які можуть бути використані як доказ факту чи обставин, що встановлюються під час кримінального провадження, то попередні дослідження ще на етапі проведення слідчої (розшукової) дії дають змогу виділити об'єкти, які стосуються події, що розслідується, та (або) потенційно можуть нести необхідну для розкриття та розслідування злочину інформацію.

Окрім цього, оскільки чинний КПК України не передбачає моменту, з якого вилучені під час слідчих (розшукових) дій об'єкти стають речовими доказами та, як і раніше, таким моментом $є$ складання відповідної постанови про визнання речовим доказом та долучення до матеріалів провадження, то завдяки попереднім дослідженням особа, яка здійснює розслідування, може визначитись із тим, які з вилучених об'єктів (особливо в разі їх значної кількості та низької якості) зараховувати до речових доказів та направляти на експертизу.

Таким чином, результати попередніх криміналістичних досліджень, тобто різноманітна інформація, отримана шляхом проведення цього різновиду техніко-криміналістичних досліджень, можуть бути використані для:

- планування та організації оперативно-розшукових заходів, розшуку злочинця, розшуку засобів та знарядь злочину та, відповідно, розкриття злочину за гарячими слідами;

- обгрунтування рішення щодо затримання особи (наприклад, у разі виявлення на руках потерпілого залишків продуктів пострілу, виявлення волокон одягу злочинця на місці події або навпаки тощо) та рішення щодо проведення невідкладних слідчих (розшукових) дій (обшуку, освідування тощо);

- висунення та перевірки окремих та загальних версій щодо події злочину, а також щодо інших елементів, які входять до складу злочину;

- реконструкціїподії,якасталасьнамісціскоєннязлочинутареконструкціїзлочинузагалом;

- моделювання невідомого злочинця, складання його криміналістичного портрету, в тому числі методом криміналістичного профілювання;

- вирішення питання про визнання об'єктів речовими доказами;

- планування, підготовки та проведення слідчих (розшукових) дій, у тому числі підготовки, призначення та оцінки криміналістичних експертиз.

Висновки. Но основі проведеного аналізу можна дійти таких висновків.

1. 3 огляду на двоїсте розуміння мети попередніх криміналістичних досліджень варто розділяти мету як кінцевий результат власне самих досліджень, що добре простежується через конкретні завдання, які ними можуть бути вирішені, та мету як напрям подальшого використання отриманої інформації, хоча інколи автори змішують ці цілі.

2. Метою попередніх криміналістичних досліджень як різновиду техніко-криміналістичних досліджень $є$ встановлення орієнтуючої інформації щодо окремих осіб, матеріальних об'єк- 
тів, а також фактів і обставин вчиненого злочину (наприклад, природи та сутності об'єктів, які виявлені в ході слідчої (розшукової) дії, об’єктів, сліди яких виявлені на місці проведення слідчої (розшукової) дії, обставин вчинення злочину; особи (осіб), яка вчинила злочин або була присутня під час його вчинення чи в інший час на місці проведення слідчої (розшукової) дії тощо).

3. Відповідно, напрями використання такої інформації досить різноманітні: від висунення і перевірки окремих та загальних версій щодо події злочину, розшуку злочинця й засобів та знарядь злочину до підготовки, призначення та оцінки криміналістичних експертиз.

4. Деталізація мети попередніх криміналістичних досліджень, на нашу думку, підкреслює важливість проведення досліджень цієї категорії під час слідчих (розшукових) дій, особливо невідкладних, а також виняткове значення інформації, отриманої в результаті таких досліджень, у розкритті та розслідуванні кримінальних правопорушень.

\section{Список використаних джерел:}

1. Великий тлумачний словник сучасної української мови : 250000 / уклад. та голов. ред. В.Т. Бусел. Київ; Ірпінь : Перун, 2005. 1728 с.

2. Торопов С.О. Попередні балістичні дослідження на місці події. Форум права. 2008. № 3. C. 485-489.

3. Корма В.Д. Предварительные криминалистические исследования следов применения оружия : учебно-практическое пособие / под ред. Е.П. Ищенко. Москва : «Приор-издат», 2007. $143 \mathrm{c}$.

4. Предварительные криминалистические исследования следов на месте происшествия : учебное пособие / А.А. Алексеев, В.Е. Капитонов, Л. И. Кошелева, А.Г. Маврин и др. Москва : ВНИИ МВД СССР, 1987. 196 с.

5. Участие специалиста-криминалиста в следственных действиях : учебное пособие / В.Н. Хрусталев, Р.Ю. Трубицын. Санкт-Петербург : Питер, 2003. 208 с.

6. Применение специальных знаний при раскрытии и расследовании преступлений / М.Г. Щербаковский, А.А. Кравченко. Харьков : Ун-т. внутр. дел, 1999. 78 с.

7. Henry Lee's Crime Scene Handbook / Henry C. Lee, Timothy Palmbach, Marilyn T. Miller. Oxford, UK : Elsevier Academic Press, 2001. 416 p.

8. Gardner Ross M. Practical crime scene analysis and reconstruction / Ross M. Gardner, Tom Bevel. Boca Raton, FL : CRC Press. 302 p.

9. Калюга К.В. До проблеми моделювання типового криміналістичного портрета злочинця в різних видах злочинів. Прикарпатський юридичний вісник. 2016. Вип. 5 (14). С. 110-114.

10. Корниенко Н.А. Теория и практика предварительных криминалистических исследований вещественных доказательств : автореф. дис. ... канд. юрид. наук : 12.00.09. Москва, 1976. 24 с.

11. Белов О.А. Предварительное исследование следов взрыва на месте происшествия. Современные проблемы науки и образования. 2014. № 6. URL: https://www.science-education.ru/ru/ article/view?id=16419. 